\title{
The influence of prefabricated pipe cement coatings and those made during pipe renovation on drinking water quality
}

\author{
Anna Młyńska ${ }^{1, *}$, and Michat Zielina ${ }^{1}$ \\ ${ }^{1}$ Cracow University of Technology, Faculty of Environmental Engineering, Institute of Water Supply \\ and Environmental Protection, ul. Warszawska 24, 31-155 Cracow, Poland
}

\begin{abstract}
Nowadays, cement coatings are often used as an anticorrosion protection of the internal surfaces of manufactured ductile iron water pipes. The protective cement linings are also commonly used for old water pipe renovation. In both cases, the cement lining is an excellent anticorrosion protection of the pipelines, effectively separating the pipe wall from the flowing water. Moreover, cement linings protect the pipelines not only by a mechanical barrier, but also by a chemical barrier creating a highly alkaline environment in water contact with the metal pipe wall. In addition, cement coatings have an ability for so-called self-regeneration and provide the improvement of hydraulic conditions inside the pipelines. In turn, the differences between the analysed cement coatings mainly depend on the types of cements used and techniques of cement mortar spraying. As was expected, they influence the quality of water having contact with the coating. A comparison of the impact of cement coatings manufactured in factories and sprayed on building sites during the renovation on drinking water quality parameters was performed in the study. The experiments were conducted in laboratory conditions, using the test stands prepared for this purpose. The results include analysis of selected water quality parameters for the samples contacting with cement mortar and collected during the investigation.
\end{abstract}

\section{Introduction}

\subsection{Protective cement mortar coatings}

Pipes made of different materials are used in water supply systems. Water pipes manufacturers offer plastic pipes made of polyethylene (PE), polyvinyl chloride (PVC) and more recently also glass reinforced plastic (GRP). However, traditional materials such as steel, iron and cast iron are still commonly used, especially for large diameter pipes working under high pressure. The limitation of the application of traditional materials for water supply system is corrosion. It can be reduced by using internal protective coatings, traditionally made of cement, but presently also often made of resins [1].

* Corresponding author: a.mlynska13@gmail.com 
The protective cement coatings are made during the manufacturing process in factories but also on building sites during the renovation of corroded water pipes [2]. Cement mortar lining is the oldest and still the most popular renovation trenchless technique for old water pipes [3]. Pipe renovation by cement mortar lining was first time performed in the 1930s [2-4]. In turn, the first water supply system consisting of iron pipes with internal cement coatings was built in 1922 [4-6].

Among many others, the most important advantages of protective cement coatings are mechanical and chemical barriers separating the metal pipe wall from the water, creation a high alkaline environment in which the corrosion process does not occur, the ability to self-regeneration $[5,6]$ and a long-term improvement of hydraulic conditions inside the pipelines $[3,6]$.

The differences between cement coatings made during manufacturing processes in factories and cement coatings prepared on building sites during renovation are mainly related to the different cement types and techniques. Blast furnace slag cement is most often used in first case [7, 8], whereas it is noted, that Portland cement is mainly used for renovation purposes. Prefabricated cement coatings are produced in two ways. In the first, cement mortar is sprayed inside the pipe rotating with a high speed; in the second, cement mortar is sprayed inside the stationary pipe by a situated centrally rotating head. In both cases, after cementing, the pipe is spun with a high velocity and then vibrated to achieve smooth and dense cement coating surface [5]. During the renovation process, the cement mortar is lined by using a centrally situated rotating head, which is pulled through the pipeline with a constant speed. The rotating velocity is also constant in order to achieve a homogenous cement coating with the same thickness along the whole water pipe cross section [2]. By using different techniques of cement coating preparation, the finally obtained protective coatings have a different microstructure and thus durability and also the probability of leaching pollutants from the lining into the water is greater or lesser. In general, cement coatings sprayed on a building site during renovation have a rather homogenous structure, whereas prefabricated coatings, lined in factories, as a consequence of pipe spinning, are characterised by the sand grains located close to the metal pipe wall inside the coating. It causes dense, smooth and less porous cement coating from the water side and the cement coating is more resistant to aggressive waters flowing through the pipe [9-11].

\subsection{The risk of water contamination resulting from contact with the cement mortar coating}

The risk of the leaching chemical elements from the cement coatings into the water is determined by the type of cement used. For example, the greatest amount of aluminium is leached from a high-alumina cement coating. In turn, the greatest amount of calcium is leached from a Portland cement coating $[9,10]$. In the case of using blast furnace slag cement for coating, the risk of leaching a greater amount of aluminium and calcium is rather small. Many experiments proved that the greatest impact of cement coating on water quality initially is mainly related to the significant growth of $\mathrm{pH}[4,10,12-15]$ and aluminium concentration $[4,10,13-15]$. It is also probable that some heavy metals will be leached from the cement coating into the water. Numerous investigations on leaching trace elements from cements into the water were conducted and described in the literature [4, 13-17].

Even a small amount of heavy metal in the human body can contribute to many different health problems. In the Netherlands, in 1996, a great amount of aluminium leaching from a new cement coating was noticed. This leached aluminium contributed to the death of some patients in a haemodialysis centre as a consequence of aluminium 
poisoning. Aluminium was leached to the water from a newly-installed water system covered inside by a protective cement coating. The concentration of aluminium was forty times higher than the specified limit [18]. Thus, the concentration of aluminium in water making contact with a cement coating in the initial period of time should be controlled.

Since both pipe cementing techniques and type of used cements significantly influence the dissolution and leaching of chemical components from the cement coating, a comparison of cement coatings manufactured in factories and prepared on a building site during renovation on water quality was performed in this study. The paper presents the change of chemical elements such as aluminium, chromium, lead and cadmium in water samples coming into contact with two different cement coatings - manufactured in a factory and prepared in a laboratory.

\section{Materials and methods}

\subsection{Tested water pipes with internal cement coatings}

In the performed experimental research, two different types of water pipes with internal cement coatings were used.

The first of them (Fig. 1a) was a piece of ductile iron water pipe with a prefabricated cement coating manufactured by one of the water pipe producers. The length of tested water pipe was about $16.0 \mathrm{~cm}$ with a nominal diameter equal to $100 \mathrm{~mm}$. The external surface of this pipe was coated with a metallic zinc-aluminium alloy and a blue epoxy layer. The internal surface of the pipe was protected by a cement coating made of blast furnace slag cement (CEM III) during the manufacturing process, with a thickness of $0.65 \mathrm{~cm}$.

In turn, the second tested water pipe sample (Fig. 1b), with a length of $25.0 \mathrm{~cm}$ and a nominal diameter of $80 \mathrm{~mm}$, was made of steel and manually coated inside with cement mortar with a thickness of $0.70 \mathrm{~cm}$. The cement mortar was prepared by mixing Portland cement (CEM I) with quartz sand in a 1:1 ratio and with water, maintaining a water to cement ratio equal to 0.35 . The curing time of the fresh cement mortar coating was $24 \mathrm{~h}$. Both the properties of the manually prepared cement coating and the curing time were the same as in the case of the cement coatings sprayed on building sites during the renovation process.
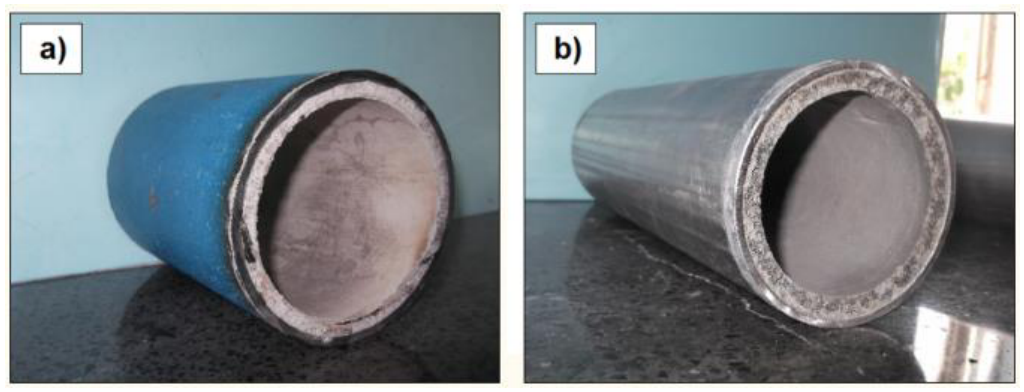

Fig. 1. Water pipes with internal cement coatings.

a) Ductile iron water pipe with prefabricated cement coating.

b) Steel water pipe with manually prepared cement coating. 


\subsection{Test stands}

Each of the two tested water pipe samples was installed on a separate test stand in the laboratory. The construction details of the two test stands are presented in Fig. 2. All of the experiments were conducted parallel in static conditions. The interiors of both samples were filled with the same water collected from the outflow of the largest water treatment plant for Cracow. The water was in contact with the cement coatings for the same periods of time. The raw water used in the experiments was relatively soft (consisting of small amount of ions), becoming rather aggressive to the cement mortar linings.

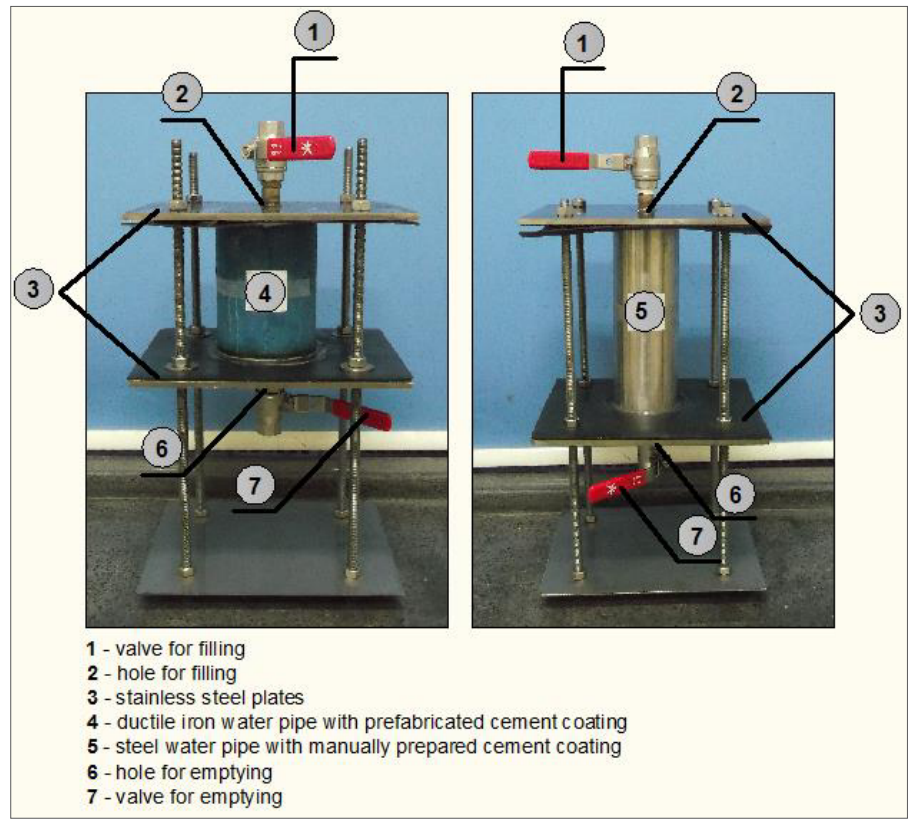

Fig. 2. Test stands for the static experiments.

\subsection{Water sampling}

The tested water samples inside the two pieces of pipes were in contact with the internal cement coatings for exactly the same periods of time. The periods were timetabled in accordance with the Dutch Standard (EA NEN 7375:2004) [19] and Polish Standard (PN-EN 14944-3:2008) [20]. During sampling, the whole amount of water from both pipe interiors was replaced with a new raw water. The waters were replaced and collected parallel soon after the following periods of time: $0.25,1,2.25,5,6,9,13,16,33,36,52$ and 56 days.

\subsection{Tested water quality parameters}

Several physicochemical water quality indices were tested for all of the water samples collected from the ductile iron pipe with prefabricated cement coating and from the interior of steel pipe with manually covered cement mortar lining and also for the raw water samples. The paper presents the results of the analysis of the aluminium, chromium, cadmium and lead concentration changes. Based on the laboratory measurements of chemical elements concentrations and also based on the methods presented in the Dutch 
Standard [19], the expected cumulative leaching of aluminium and chromium from $1 \mathrm{~m}^{2}$ of the cement mortar coating surface into the water was counted and presented below.

\section{Leaching contaminations from cement coatings into the water - results and discussion}

\subsection{Aluminium leaching}

It is clearly evident from Fig. 3 that the aluminium was leached much more intensively from the manually prepared cement coating into the water than from prefabricated cement coating for the whole period of the investigation.

The greatest amount of the leached aluminium from the manually prepared cement coating, exceeding even $20.0 \mathrm{mg} / \mathrm{m}^{2}$, was noticed during the first 5 days of its contact with water. After this time, the amount of leached aluminium was gradually decreased and on day 56 of the experiment, the leaching had totally stopped. In turn, for the prefabricated cement coating, a small leaching of aluminium, equal to $0.14 \mathrm{mg} / \mathrm{m}^{2}$, was noticed just after 2 days of contact with water. In the 33-day experiment, again some increase of leaching $\left(0.34 \mathrm{mg} / \mathrm{m}^{2}\right)$ was observed, whereas almost a total lack of any leaching was noticed till the end.

For the whole investigation period, about $160 \mathrm{mg}$ of aluminium in total was leached from $1 \mathrm{~m}^{2}$ of the manually prepared cement coating surface, whereas only about $0.50 \mathrm{mg} / \mathrm{m}^{2}$ was leached from the prefabricated cement lining. It shows that the total amount of aluminium leached from the cement coating made during renovation can be even more than three hundred times more than that from a prefabricated cement coating.

Since aluminium is important component of Portland cement, leaching of aluminium from manually prepared coating is much more intensive than from prefabricated cement coating covering inner side of the pipe. In turn, the amount of aluminium contained in prefabricated mortar lining made of blast furnace slag cement is much smaller.

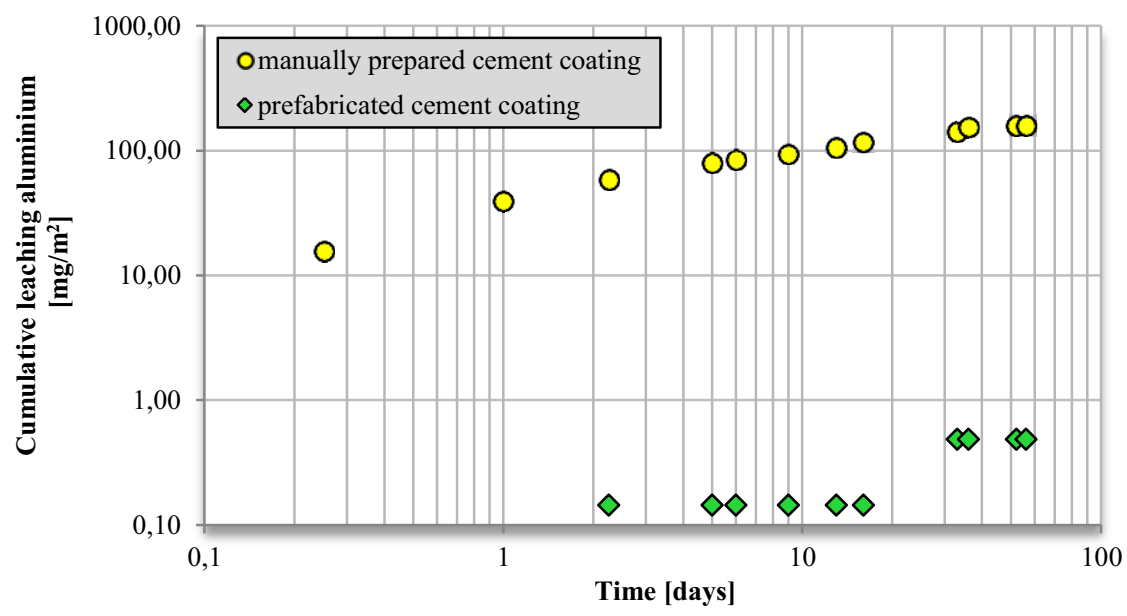

Fig. 3. Cumulative leaching of aluminium from manually prepared and prefabricated cement coatings. 


\subsection{Chromium leaching}

In comparison to aluminium, chromium was leached from the both analysed cement coatings much less intensively (Fig. 4).

In the case of the manually prepared cement coating, the most intensive chromium leaching was noted during the first day of contact with water. In the following days, the intensity of the leaching process was smaller and at the end of the study period chromium leaching had stopped. The total, cumulative amount of leached chromium from cement coating made of Portland cement was a little over $4.5 \mathrm{mg} / \mathrm{m}^{2}$ and thus, was about thirty-five times smaller than the total cumulative amount of leached aluminium. In the case of prefabricated cement coating, only during the first $6 \mathrm{~h}$ of contact with water, $0.024 \mathrm{mg}$ of chromium from $1 \mathrm{~m}^{2}$ of cement coating was leached. As can be seen, the risk of leaching chromium from cement coatings made during the renovation process is much greater than in the case of prefabricated coatings. Nevertheless, in none of the two cases is there any serious risk of exceeding concentration limits by the leaching of chromium from the inner cement linings. Only high concentration of chromium in raw water could be threatening to human health.

The same as in case of the aluminium, it was observed much more intensive leaching of chromium to water contacting with manually prepared cement coating than to water contacting with prefabricated coating. It was due to different types of cement used in preparation of both specimens and also different methods of preparation.

However, since chromium is one of the trace elements in cement, chromium was leached from both kinds of coating less intensive than aluminium.

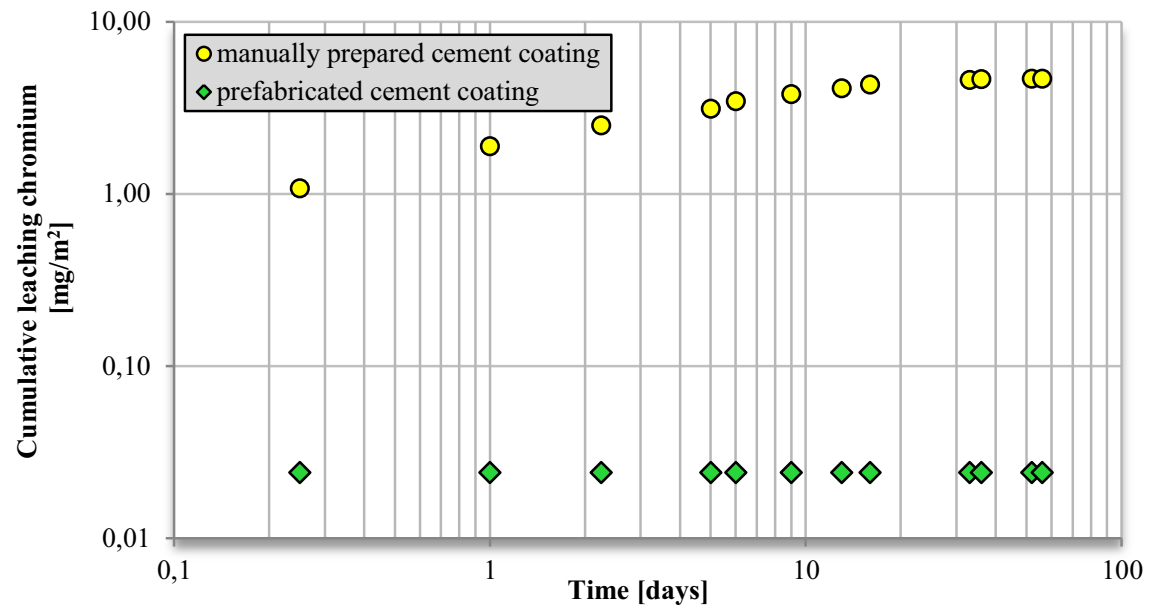

Fig. 4. Cumulative leaching of chromium from manually prepared and prefabricated cement coatings.

\subsection{Lead and cadmium leaching}

In all collected water samples, the concentrations of lead and cadmium were very low from contact with the prefabricated and manually prepared cement coatings. The concentration of lead was five times smaller than its limitation value according to drinking water standards [21], while the cadmium concentration was as much as ten times smaller than the maximum value regulated by [21]. It confirms that the risk of leaching of toxic heavy metals from both analysed cement coatings into the water was negligible because of low heavy metal contents in both cements. 


\section{Conclusions}

Both kinds of internal cement coating, manufactured in factories and made during the renovation of old pipes, guarantee relatively good protection against corrosion. However, due to different techniques of lining, the coatings are characterised by different microstructures. The structure made during renovation is quite homogenous and porous in the whole cross section, whereas a prefabricated coating consists of two parts. The first part, which attaches to pipe wall, consists of a cumulated amount of sand grains, whereas the second part, which makes contact with water, is quite smooth and dense, without many sand grains. It results in the prefabricated cement coating to be more durable and resistant to dissolution and leaching out of chemical components.

The conducted experiments suggest that some risk of leaching contaminations from the both analysed cement coatings is only related to aluminium. Leaching of dangerous heavy metals such as chromium, lead or cadmium was revealed to be very low or negligible. As was expected, the most significant leaching of all pollutants was observed during the initial period.

Based on the experiments, it was found that the leaching of aluminium and chromium from coatings made during renovation is much more intensive than from prefabricated coatings made in factories.

The risk of drinking water contamination from the fresh cement coating soon after renovation process seem to be relatively low. However, it is still important to determine an appropriate contact time of fresh cement mortar lining with flowing water, as well as the composition of the mortar, flushing velocity and time.

Prefabricated cement coatings seem to be quite safe for drinking water. Even soon after the pipe installation, any exceeding of drinking water quality parameters is not expected.

However, some other experiments concerned water pipe lining should be done in the future, e.g. investigating the influence of different cement types for pipe renovation or hydraulic conditions on drinking water quality. The results of such experiments will help to determine the maximum allowable length of pipe put under renovation depending on pipe diameter, hydraulic conditions or cement types.

\section{References}

1. G. Tsakiris, V. Tsakiris, Pipe technologies for urban water conveyance distribution systems, Water Utility Journal, 3, 29-36 (2012)

2. American Water Works Association, Rehabilitation of water mains, Manual of water supply practices-M28, Second Edition (AWWA, Denver 2001)

3. N. Damodaran, J. Pratt, J. Cromwell, J. Lazo, E. David., R. Raucher, Ch. Herrick, E. Rambo, A.K. Deb, J. Snyder, Customer acceptance of water main structural reliability (AwwaRF, Denver 2005).

4. A.K. Deb, S.B. McCammon, J. Snyder, A. Dietrich, Impacts of lining materials on water quality (Water Research Foundation, Denver 2010)

5. American Water Works Association, Ductile-iron pipe and fittings, Manual of water supply practices-M41, Second Edition (AWWA, Denver 2002)

6. R.W. Bonds, Cement-mortar linings for ductile iron pipe (Ductile Iron Pipe Research Association, Alabama 2005)

7. Information materials of Duktus Company

8. Information materials of Saint-Gobain PAM UK

9. I.S. Meland, Durability of mortar linings in ductile iron pipes, Durability of Building Materials and Components 8: Proceedings of the Eighth International Conference on Durability of Building Materials and Components, 170-179 (Vancouver 1999) 
10. M. Zielina, W. Dąbrowski, E. Radziszewska-Zielina, Cement mortar lining as a potential source of water contamination, World Academy of Science, Engineering and Technology, 8(10), 636-639 (2014)

11. A. Wassilkowska, K. Kuc, M. Zielina, A study of the composition of cement mortar lining in water and sewage pipelines, Technical Transactions, Civil Engineering, 4-B, 131-136 (2015)

12. A.J. Whelton, M. Salehi, M. Tabor, B. Donaldson, J. Estaba, Impact of infrastructure coating materials on storm-water quality: Review and experimental study, Journal of Environmental Engineering, 139(5), 746-756 (2013)

13. M. Zielina, A. Młyńska, T. Żaba, Experimental research on deterioration of drinking water quality after cement mortar pipe lining, Technical Transactions, Civil Engineering, 4-B, 145-152 (2015)

14. A. Młyńska, M. Zielina, Experimental research on the impact of different hardness waters on their contamination by protective cement mortar linings after pipe renovation, Technical Transactions, Environment Engineering, 1-Ś, 97-104 (2016)

15. M. Zielina, A. Młyńska, T. Żaba, Przenikanie zanieczyszczeń z wyprawy cementowej do wody pitnej $w$ przewodach wodociagowych po cementowaniu, Zaopatrzenie w wodę, jakość i ochrona wód, 535-544 (PZIiTS, Poznań, Toruń 2014)

16. B. Kowalska, D. Kowalski, M. Kwietniewski, K. Miszta-Kruk, J. Chudzicki, Badania zawartości jonów metali ciężkich w wodzie kontaktującej się z wyktadzina cementowa rur wodociagowych, Ochrona Środowiska, 33(4), 41-45 (2011)

17. Q. Guo, P.J. Toomuluri, J.O. Eckert, Leachability of regulated metals from cement mortar linings, Journal AWWA, 90(3), 62-73 (1998)

18. K. Berend, T. Trouwborst, Cement-mortar pipes as a source of aluminum, Journal AWWA, 91(7), 91-100 (1999)

19. EA NEN 7375:2004, Leaching characteristics of moulded or monolithic building and waste materials/Determination of leaching of inorganic components with the diffusion test - "The tank test", Netherlands Normalisation Institute Standard, Aprol 2005

20. PN-EN 14944-3:2008, Wpływ wyrobów cementowych na wodę przeznaczoną do spożycia przez ludzi - Metody badań - Część 3: Migracja substancji z produkowanych fabrycznie wyrobów cementowych, Luty 2008

21. Rozporządzenie Ministra Zdrowia z dnia 13 listopada 2015 roku w sprawie jakości wody przeznaczonej do spożycia przez ludzi (Dz.U. 2015 poz. 1989) 